\title{
Sports Access Learning (SAL) to Promote Self- Regulated Learning: a Need Analysis
}

\author{
Wasis Djoko Dwiyogo, Supriyadi, Sapto Adi \\ Sport Education \\ Universitas Negeri Malang \\ Malang, Indonesia \\ wasis.djoko.fik@um.ac.id
}

\begin{abstract}
This study aimed to capture the need analysis of sports access learning (SAL) in to promote self-regulated learning for sports education students. The participants of this survey were 89 students of bachelor degree and master degree of sports education at the State University of Malang. This study was conducted as a descriptive research using survey design to collect the data related to the need analysis of SAL. The results of this study explored the variety of the activities in using the internet, facilities in accessing the internet, blended learning environment in learning, and the need of SAL. The second finding showed that the samples have an adequate self-regulated learning level. In general, the SAL development is highly needed for students of sports education to enhance the self-regulated learning level. The implications of the findings in SAL are also discussed.
\end{abstract}

Keywords: information and technology, sports access learning, self-regulated learning

\section{Introduction}

The tendency of learning nowadays and the future has changed the traditional learning approach to the learning that is called learning in the knowledge era that demonstrates science and technology of sport and can be useful and accessible for many users anywhere and anytime, through textbooks, experts, peers, children, internet, radio, television, and many more media.

The characteristics of learning in the century of knowledge are the lecturers become the facilitators, counsellors and consultants, the lecturers become the friends of learning, the learning is directed by people who learn, the learning is open and flexible, the learning is mainly based on the projects, problems, and the learning is oriented to the empirical world with concrete actions. Furthermore, the other characteristics of learning are the inquiry and design methods, discovering and creating, collaborative, community-focused, open-ended result, creative diversity, computers as a tool of all kinds of learning, dynamic multimedia interaction and communication.

The rapid and vast development of technology has impacted the education field, where the lecturer nowadays is required not only to teach the students but also to consider how the environment and source of information can support the learning process. Another impact is various learning media are being created such as textbook, power point slides, video, movie, hypertext, web and many other forms. A professional lecturer should have explored which learning media can be helpful to the learning process.

Learning is a process where we manage the external factors to support the internal factors. The learning target is to modify the external factors as well as the environment to influence and to produce the willingness to learn. One of the strategies is to provide the learning sources such as lecturer, text book, learning material, guest speaker, TV, DVD, radio, magazine, newspaper, internet, $\mathrm{CD}$, environment or peer educator. The measure of a successful learning process is the interaction between a learning person and his/her learning sources. Hence, modifying the learning sources is a crucial step. The learning sources need to be created to engage the learner and to make the learning process more effective, efficient and interesting. Furthermore, the role of a lecturer will transform to an organizer of learning sources to make the learning easier, faster, more practical and more fun.

A learning source centre equipped with informative technology should be developed. In the learning centre, all people who want to learn can access all forms of learning media, such as a journal, encyclopaedia, magazine, newspaper, video, cassette and internet. Furthermore, they can learn anytime through any media. However, to build this centre, we need the goodwill from community and a transparent management.

One of the challenges for sports education in the future is associated with the use of better technology [1]. Nowadays, one of the most crucial features of the last several decades is the incredible progression of technology [2]. Thus, this phenomenon leads some development. Therefore, the urgency of developing the learning sources is mainly to lower the gaps between learning based on face-to-face oriented in classroom to the learning combining the online and offline learning.

There is an urgent need to build a centre which can reduce the gap between an ordinary learning process in the classroom and a learning process involving interactive media based on the technology. We have developed the Sports Access Learning (SAL) as a learning source which can be accessed at any time so that it can be used to bridge the gap.

Furthermore, various studies have shown that physical education or sports is not only limited to the face to face 
learning condition, but also the renewal related to the integration of technology by the physical education learner. The technology which is integrated into physical education is broadly associated with the use of computer technology, monitoring of physical activity, and multimedia [3], Nitendo Wii [4], video feedback such as audio-visual [5], PowerPoint, YouTube, Pedometers, Heart Rate monitor, and Coaches Eye [6], clickers [7], and Exergames [8].

SAL is an ATM-like machine equipped with software to expand the student's access to learning sources both offline and online. The appearance of SAL is displayed in Fig. 1. The machine stores all information related to the Sports Sciences Postgraduate Course in the State University of Malang. Hence, it can be used as a learning source for the students. SAL interface has main menu and submenu in various formats such as Macro Media Flash, Microsoft Words and PowerPoint, PDF, and video. What we have stored in SAL can be accessed in two ways, first by accessing it through the touch screen and the second is by using the personal laptop since SAL also works as a server connected to the same internet connection (WiFi). It also functions as an offline learning source as it is presented in Fig. 2.

The content of SAL in the main menu includes text, picture, video and animation of: (1) The Sports Science Postgraduate Course Profile, (2) Acknowledgement from The Head of the University, The Director and the Head of the Department, (3) Curriculum, (4) Course description, (5) Lecturers' profile, (6) Research journals from the lecturers, (7) Research journal from students, (8) Sports policies, (9) Sports and Technology, (10) E-book, and (11) Sports video. These entire main menus are divided into sub-menus.

The research is highly essential to be done to produce an empiric result for the quality development of the university, particularly the Sports Sciences Postgraduate Course. The result of the research will include the learning source models for SAL based on the technology at offline state as well as online. The development of the model will support postgraduate students to manage and provide learning sources. This particular model will increase the quality of the learning process and the efficiency of time to learn. Furthermore, the research result will be used as a development model of learning sources based on the technology as a particular characteristic of Physical Education and Sports Sciences Course.

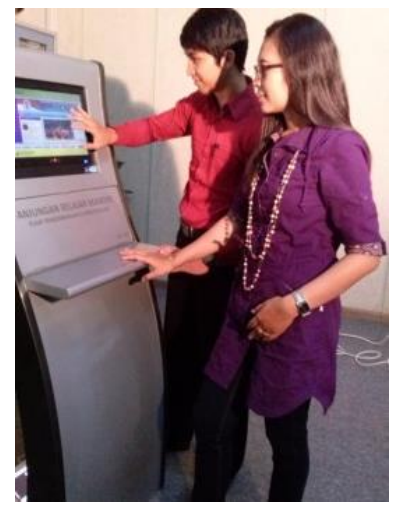

Fig. 1. The Appearance of SAL (Source: documentation of researcher)

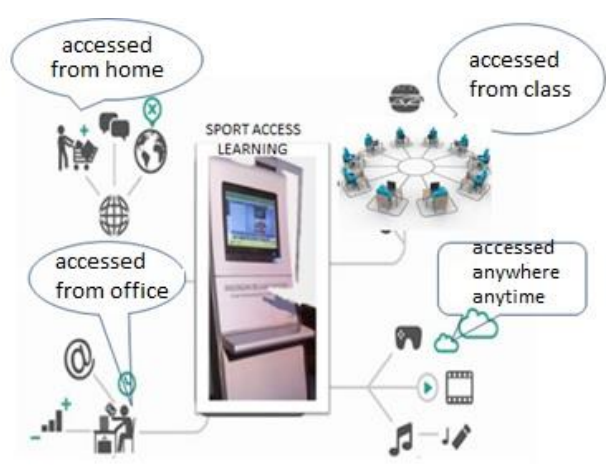

Fig. 2. Concept Model of SAL

The research will involve the postgraduate students of Sports Sciences Course in the development of the instrument, in the teacher and lecturer survey of their learning syllabus and in filling the content of the syllabus. In general, the research will be valuable as the theory-research primary finding in the development of learning technology and to be used in another research of the function of producing learning sources [9]-[11]. This study aimed to collect the need analysis data and determine the specifications and components of Sports Access Learning (SAL) development for graduate student of Sports Education at the State University of Malang. Furthermore, the result of the research will be a web-form based that consists of teaching materials, presentation and learning based on the computer as the learning sources.

\section{METHODS}

This study was conducted as a descriptive survey related to need analysis of SAL. The participants of this study were 89 student of bachelor and master degree of sports education program at the State University of Malang. The samples compositions were $43 \%$ was bachelor degree and $57 \%$ was master degree. The questionnaire consisted of two parts, which the first part gained data about internet usage of the student and the second one was conducted to explore the self-regulated learning aspects of students that was build using Linkert scale. This study used a semi-structured questionnaire consisting of the general characteristics of the subjects, activities in using the internet, facilities in accessing the internet, blended learning environment in learning, the need of SAL, and a structured questionnaire assessing self-regulated learning level of Sports Education student at the State University of Malang. Based on reliability analysis, Cronbach's Alpha of the second part questionnaire that consisted of 15 questions were 0,865 that can be stated reliable.

\section{RESULTS AND DISCUSSION}

In this section, the findings are presented in two parts. The first part explores a variety of activity in using the internet, facilities in accessing the internet, blended learning environment in learning, and the need of SAL are displayed in Table 1. The second part describes theself-regulated learning level of participants that is displayed in Table 2. 
TABLE I. SUMMARY OF NEED ANALYSIS QUESTIONNAIRE BASED ON INTERNET USAGE, FACILITIES, BLENDED LEARNING (BL), AND SPORTS ACCESS LEARNING (SAL)

\begin{tabular}{|c|c|c|c|c|c|c|c|}
\hline No & Component & $\mathbf{N}$ & $\%$ & No & Component & $\mathbf{N}$ & $\%$ \\
\hline \multicolumn{4}{|c|}{ Internet Usage } & \multicolumn{4}{|c|}{ Blended Learning } \\
\hline 1 & \multicolumn{3}{|l|}{ Duration } & 1 & \multicolumn{3}{|c|}{ Online learning participation } \\
\hline & Under 2 hours & 30 & 33,7 & & As a student & 75 & 67,2 \\
\hline & $2-3$ hours & 17 & 19,1 & & As a teacher & 13 & 15,1 \\
\hline & $3-4$ hours & 19 & 21,3 & 2 & \multicolumn{3}{|l|}{ Usability } \\
\hline & $4-5$ hours & 8 & 9 & & Very useful & 63 & 71,1 \\
\hline & Over 5 hours & 15 & 16,9 & & Useful & 26 & 28,9 \\
\hline 2 & \multicolumn{3}{|l|}{ Place } & & Useless & 0 & 0 \\
\hline & Home & 69 & 77,5 & 3 & \multicolumn{3}{|l|}{ Acceptance } \\
\hline & Campus & 49 & 55,1 & & Strongly agree & 49 & 55,1 \\
\hline & $\begin{array}{l}\text { Warnet } \\
\text { (Internet Cafe) }\end{array}$ & 7 & 7,9 & & Agree & 40 & 44,9 \\
\hline \multicolumn{4}{|c|}{ Facilities } & & Disagree & 0 & 0 \\
\hline 1 & \multicolumn{3}{|l|}{ Hardware } & 4 & \multicolumn{3}{|l|}{ Composition } \\
\hline & $\begin{array}{l}\text { Personal } \\
\text { Computer } \\
\text { (PC) }\end{array}$ & 3 & 3,4 & & Face to face $100 \%$ & 30 & 33,3 \\
\hline & Laptop & 34 & 38,2 & & \multirow{2}{*}{$\begin{array}{l}\text { Face to face } 75 \% \text {, } \\
\text { online and offline } \\
25 \%\end{array}$} & \multirow[t]{2}{*}{15} & \multirow[t]{2}{*}{16,7} \\
\hline & $\begin{array}{l}\text { Handphone } \\
\text { (smartphone) }\end{array}$ & 64 & 71,9 & & & & \\
\hline \multirow[t]{5}{*}{2} & \multicolumn{3}{|l|}{ Monthly cost } & & \multirow{2}{*}{$\begin{array}{l}\text { Face to face } 50 \% \text {, } \\
\text { online } 25 \% \text {, offline } \\
25 \%\end{array}$} & \multirow[t]{2}{*}{45} & \multirow[t]{2}{*}{50} \\
\hline & $\begin{array}{ll}\text { Under } & \text { Rp } \\
100.000 & \\
\end{array}$ & 71 & 79,8 & & & & \\
\hline & $\begin{array}{l}\text { Rp } 100.000- \\
\text { Rp 200.000 }\end{array}$ & 9 & 15,7 & & \multirow{2}{*}{$\begin{array}{l}\text { Face to face } 25 \% \text {, } \\
\text { online } 25 \% \text {, offline } \\
50 \%\end{array}$} & \multirow[t]{2}{*}{0} & \multirow[t]{2}{*}{0} \\
\hline & $\begin{array}{l}\text { Rp } 200.000- \\
\text { Rp } 300.000\end{array}$ & 3 & 3,4 & & & & \\
\hline & $\begin{array}{ll}\text { Over } & \text { Rp } \\
300.000 & \\
\end{array}$ & 1 & 1,1 & & & & \\
\hline \multirow[t]{4}{*}{3} & \multicolumn{3}{|c|}{ Internet access at faculty } & \multicolumn{4}{|c|}{ Sports Access Learning (SAL) } \\
\hline & $\begin{array}{l}\text { Effortless and } \\
\text { fast }\end{array}$ & 18 & 20,2 & 1 & Usability & & \\
\hline & Easy and slow & 54 & 60,7 & & Very useful & 41 & 45,6 \\
\hline & $\begin{array}{l}\text { Difficult and } \\
\text { slow }\end{array}$ & 17 & 19,1 & & Useful & 46 & 52,2 \\
\hline 4 & $\begin{array}{l}\text { Internet access } \\
\text { at class }\end{array}$ & & & & Useless & 2 & 2,2 \\
\hline & $\begin{array}{l}\text { Effortless and } \\
\text { fast }\end{array}$ & 11 & 12,4 & 2 & \multicolumn{3}{|l|}{ Content } \\
\hline & Easy and slow & 59 & 66,3 & & Textbook & 0 & 0 \\
\hline & $\begin{array}{l}\text { Difficult and } \\
\text { slow }\end{array}$ & 19 & 21,3 & & Textbook, audio & 0 & 0 \\
\hline 5 & \multicolumn{3}{|c|}{ Electronic learning sources } & & $\begin{array}{ll}\text { Textbook, audio, } \\
\text { and video }\end{array}$ & 14 & 15,7 \\
\hline & $\begin{array}{l}\text { Very } \\
\text { sufficient }\end{array}$ & 8 & 8,9 & & \multirow{3}{*}{$\begin{array}{l}\text { Multimedia } \\
\text { interactive: } \\
\text { textbook, audio, } \\
\text { video, } \\
\text { animation }\end{array}$} & \multirow[t]{3}{*}{12} & 13,5 \\
\hline & Sufficient & 61 & 68,9 & & & & \\
\hline & Deficient & 20 & 22,2 & & & & \\
\hline & & & & & $\begin{array}{l}\text { Multimedia } \\
\text { interactive: } \\
\text { textbook, audio, } \\
\text { video, animation, } \\
\text { and internet }\end{array}$ & 63 & 70,8 \\
\hline
\end{tabular}

According to Table 1, the majority of the participants stated that they only use the active internet less than 3 hours per day $(33,3 \%)$ and most of them accessed the internet when they are in the home $(77,5 \%)$ and campus area $(55,1 \%)$. Internet cafe (warnet) now becomes less popular in young people. Besides that, based on the current survey result in Indonesia, most regions are dominated by Wi-Fi broadband internet connection and cellular access (mobile broadband) is mostly used in East Java [12].

The next component discussed are facilities that consist of hardware, monthly cost, internet access and electronic sources. More than 70 percent of respondents used a mobile phone (smartphone) to access the internet. This finding can be correlated with the survey result of smartphone users in Indonesia that increased 12 million from 2015 to 2016 [13] and is estimated to reach 62, 69 million in 2017 [14]. In addition, this number is projected to increase about 10 million per year.

According to Table 1, $71(79,8 \%)$ respondents spend less than Rp 100.000 to buy data service in each month while only one person that spends more than Rp 300.000 per month. Depending on the current survey, mobile data in Indonesia costs only 50 percent of what the other ASEAN country pay to access the internet or in other words the mobile data cost in Indonesia is very affordable [13]. Thus, this survey also leads a consequence that the connection speed is below the average (very low).

The data related to the accessibility of internet speed at faculty and area near the classes are also displayed in Table 1. According to the result findings, internet access in classes and faculty area are categorized as easy and slow with more than $60 \%$ respondents who chose that option. This also can be a limitation to provide a better opportunity for a student in accessing the online learning. Some studies also revealed some barriers related to the applications of blended learning in their schools or universities. One of the negative impressions came from the technical field that is related to the server that went down when all students accessed the site at the same time [15].

The third component accessed is related to the blended learning environment in learning consisting of participation, usability, acceptance, and composition. Based on the data displayed in Table 1, 75 respondents $(67,2 \%)$ said that they participated as a student in online learning, while only $15,1 \%$ enrolled as a teacher. Next component discussed is the usability of blended learning which is found clearly from Table 1 that most participant stated as very useful with more than $70 \%$ participants said that. Moving to acceptance of blended learning, the percentage of two categories that strongly agree and agree almost share the same amount of respondent, while no one said disagree. The next component discussed is the composition. According to Table 1, 50\% exactly of respondents chosen combination of face to face $(50 \%)$, online (25\%), and offline (25\%) to be the best composition in their learning. In contrast, full-time face to face learning still is chosen by $33,3 \%$ respondents. In general, most respondents agree to choose the fourth composition that combines face to face learning $(50 \%)$, online $(25 \%)$, and offline $(25 \%)$. 
TABLE II. DISTRIBUTION OF SELF-REGULATED LEARNING RESPONSES

\begin{tabular}{|c|c|c|c|c|c|c|c|c|c|c|c|c|c|}
\hline \multirow[t]{2}{*}{ No } & \multirow[t]{2}{*}{ Question } & \multicolumn{10}{|c|}{ Responses } & \multirow[t]{2}{*}{ Mean } & \multirow[t]{2}{*}{ Std. Dev } \\
\hline & & & $S A$ & & $\bar{A}$ & & $N$ & & $\bar{D}$ & & $\overline{S D}$ & & \\
\hline 1 & Question 1 & 40 & $45 \%$ & 40 & $45 \%$ & 9 & $10 \%$ & 0 & $0 \%$ & 0 & $0 \%$ & 4,361 & 0,654 \\
\hline 2 & Question 2 & 26 & $29 \%$ & 52 & $58 \%$ & 9 & $10 \%$ & 1 & $1 \%$ & 0 & $0 \%$ & 4,156 & 0,652 \\
\hline 3 & Question 3 & 16 & $18 \%$ & 47 & $53 \%$ & 25 & $28 \%$ & 0 & $0 \%$ & 0 & $0 \%$ & 3,879 & 0,669 \\
\hline 4 & Question 4 & 22 & $25 \%$ & 44 & $49 \%$ & 22 & $25 \%$ & 1 & $1 \%$ & 0 & $0 \%$ & 3,927 & 0,728 \\
\hline 5 & Question 5 & 16 & $18 \%$ & 44 & $49 \%$ & 26 & $29 \%$ & 3 & $3 \%$ & 0 & $0 \%$ & 3,771 & 0,754 \\
\hline 6 & Question 6 & 21 & $24 \%$ & 47 & $53 \%$ & 16 & $18 \%$ & 3 & $3 \%$ & 0 & $0 \%$ & 3,963 & 0,756 \\
\hline 7 & Question 7 & 9 & $10 \%$ & 22 & $25 \%$ & 44 & $49 \%$ & 12 & $13 \%$ & 2 & $2 \%$ & 3,216 & 0,870 \\
\hline 8 & Question 8 & 11 & $12 \%$ & 41 & $46 \%$ & 29 & $33 \%$ & 7 & $8 \%$ & 1 & $1 \%$ & 3,602 & 0,825 \\
\hline 9 & Question 9 & 13 & $15 \%$ & 53 & $60 \%$ & 15 & $17 \%$ & 6 & $7 \%$ & 0 & $0 \%$ & 3,807 & 0,756 \\
\hline 10 & Question 10 & 24 & $27 \%$ & 52 & $58 \%$ & 12 & $13 \%$ & 1 & $1 \%$ & 0 & $0 \%$ & 4,108 & 0,662 \\
\hline 11 & Question 11 & 14 & $16 \%$ & 58 & $65 \%$ & 16 & $18 \%$ & 0 & $0 \%$ & 1 & $1 \%$ & 3,915 & 0,647 \\
\hline 12 & Question 12 & 21 & $24 \%$ & 50 & $56 \%$ & 14 & $16 \%$ & 4 & $4 \%$ & 0 & $0 \%$ & 3,963 & 0,772 \\
\hline 13 & Question 13 & 24 & $27 \%$ & 41 & $46 \%$ & 19 & $21 \%$ & 3 & $3 \%$ & 1 & $1 \%$ & 3,927 & 0,866 \\
\hline 14 & Question 14 & 16 & $18 \%$ & 33 & $37 \%$ & 32 & $36 \%$ & 6 & $7 \%$ & 1 & $1 \%$ & 3,614 & 0,894 \\
\hline 15 & Question 15 & 29 & $33 \%$ & 53 & $60 \%$ & 10 & $11 \%$ & 2 & $2 \%$ & 0 & $0 \%$ & 4,120 & 0,705 \\
\hline
\end{tabular}

a. Note: $\mathrm{SA}=$ strongly agree, $\mathrm{A}=$ agree, $\mathrm{N}=$ neutral, $\mathrm{D}=$ disagree, $\mathrm{SD}=$ strongly disagree

According to Table 1, the last component displayed is the need for Sports Access Learning (SAL). The first component presents data about the usability of SAL and the second data shows the content of SAL development. Based on the data, 70, $8 \%$ respondents said that the content of SAL wanted consists of text, audio, video, multimedia interactive, and the internet. In addition, the two categories are a combination of text, audio, video, and multimedia interactive and the combination of text, audio, video, and animation almost split the same number of responses.

Support appears through the perception toward mastery of the technology considered at a high level by teachers or prospective teachers of sports education [16], [17]. This case indicates an important need for improvement of professional quality in terms of technology mastery. One of the key concepts to experience better understanding of using technology into learning is usually connected to the selfregulated learning.

This study also revealed data of self-regulated learning that consisted of 15 questions which are presented in Table 2. The mean of responses to each question is mostly categorized as a neutral response, while only three questions that have mean above 4 (agree), namely question 1 , question 2 and question 10. According to Table 2 the distribution of responses commonly placed in the three categories that ranged from strongly agree, agree and neutral. Only question number 7 and 8 that have various distribution. To sum up, the mean of the responses is neutral with small amount of standard deviation.

Based on the previous data summary, the next data displayed shows the categories of the respondent that is related to the self-regulated learning levels in interval data. Based on the calculation gained from total scores there are five
TABLE III. SUMMARY OF SELF-REgULATED LEARNING RESPONSES

\begin{tabular}{|l|l|l|l|}
\hline No & Total Skor & N & \% \\
\hline 1 & $>40$ & 0 & 0 \\
\hline 2 & $41-50$ & 8 & 9 \\
\hline 3 & $51-60$ & 51 & 57,3 \\
\hline 4 & $61-70$ & 24 & 27 \\
\hline 5 & $71-80$ & 6 & 6,7 \\
\hline \multicolumn{2}{|l|}{ Jumlah } & 89 & 100 \\
\hline
\end{tabular}

categories displayed in Table 3 ranging from score $>40,41-50$, $51-60,61-70$, and 71-80 with maximum score is 75 .

According to Table 3, more than $50 \%$ of respondents are categorized as moderate self-regulated learning level, whereas 24 respondents are categorized in high self-regulated learning level, and only six respondents have very high self-regulated learning level. In contrast, from the data showed, there is no respondent categorized as low self-regulated learning level. The results showed thatthe students have enough and high self-regulated learning level.

Research on self-regulated learning and information technology had been done to show some relationships. Thus, the high level of self-regulated learning is the crucial component to integrate blended learning model in sports education students. Ting and Chao [18] observed the application of self-regulated strategies in blended learning using Moodle and the results showed that the students with a high level of competence performed were better than those with the intermediate level although there is no significant difference related to the gender. Another study showed that self-regulated learning strategy was used successfully in 
increasing the metacognitive students in the online learning environment [19].

\section{CONCLUSION}

The rapid and vast development of technology has impacted the education field, where lecturer nowadays is not only required to teach students but also to consider how the environment and source of information can support the learning process. This study indicates that mostly sports science students agree that there is a need of the development of SAL and the contents of SAL wanted consist of text, audio, video, multimedia interactive, and the internet. This study also explored the self-regulated learning level of student that majority of themstand in a high level of self-regulated learning.

In particular, the result of this research can be used as a lifebased learning (through classroom, offline or online) both for lecturers and postgraduate students of Sports Sciences at the State University of Malang. The students can use it to facilitate the learning sources in the other courses using SAL. Future study is needed especially in developing the SAL using research and development ( $\mathrm{R} \& \mathrm{D})$.

\section{REFERENCES}

[1] M. M. Buck, J. T. Jable, and P. A. Flyod, Introduction to Physical Education and Sport: Foundations and Trends. Belmont, CA: Wadsworth-Thomson, 2004.

[2] I. Okan, "The Use of Computer Competencies of Students in the Departments of Physical Education and Sport Teaching, and School Teaching," Int. J. Environ. Sci. Educ., vol. 11, no. 15, 2016.

[3] S. Chen and Y. Xia, "Research on application of multimedia technology in college physical education," Procedia Eng., vol. 29, no. 2012, pp. 4213-4217, 2012.

[4] D. Perlman, G. Forrest, and P. Pearson, "Nintendo Wii: Opportunities to Put the Education Back into Physical Education," Aust. J. Teach. Educ., vol. 37, no. 7, pp. 85-94, 2012.

[5] C. Mereuta and E. Mereuta, "Psychomotor stimulation of students in physical education using audiovisual media," Procedia-Social Behav. Sci., vol. 84, no. 2013, pp. 1611-1616, 2013.

[6] H. Baert, "The Effects of Role Modeling on Technology Integration within Physical Education Teacher Education," JTRM Kinesiol., pp. 126, 2014.
[7] V. Constantinou and A. Ioannou, "Technology-enhanced learning in sports education using clickers: Satisfaction, performance and immediacy," Int. J. Educ. Dev. Using Inf. Commun. Technol., vol. 12, no. 2, pp. 68-79, 2016.

[8] B. Gibbs, M. Quennerstedt, and H. Larsson, "Teaching dance in physical education using exergames," Eur. Phys. Educ. Rev., vol. 23, no. 2, pp. 237-256, 2017.

[9] Association for Educational Communications and Technology (AECT), "Educational Technology: A Glossary of Terms," Washington, DC, 1977.

[10] A. Januszewski and M. Molenda, Educational Technology: A definition with Commentary. New York: Lawrence Erlbaum Associates, 2008.

[11] B. B. Seels and R. C. Richey, "Instructional Technology: The Definition and Domains of The Field," Washington, DC, 1994.

[12] Asosiasi Penyelenggara Jasa Internet Indonesia (APJII), "Indonesia Internet Usage for Business Sector 2013," Badan Pusat Statistik (BPS), 2013. [Online]. Available: https://apjii.or.id/downfile/file/SurveiPenggunaanInternetSektorBisnis2 013versienglish.pdf.

[13] K. Das, M. Gryseels, P. Sudhir, and K. T. Tan, "Unlocking Indonesia's digital opportunity," McKinsey \& Company, 2016. .

[14] Statista, "A number of smartphone users in Indonesia from 2011 to 2022 (in millions)," www.statista.com, 2017. .

[15] S. A. Gyamfi and P. O. Gyaase, "Students' perception of blended learning environment: A case study of the University of Education, Winneba, Kumasi-Campus, Ghana," Int. J. Educ. Dev. using Inf. Commun. Technol., vol. 11, no. 1, pp. 80-100, 2015.

[16] G. Hergüner, "Tablet Computer Literacy Levels of the Physical Education and Sports Department Students," Malaysian Online J. Educ. Technol., vol. 4, no. 2, pp. 58-65, 2016.

[17] Y. Kalemoglu Varol, "The Relationship between attitudes of prospective physical education teachers towards education technologies and computer self-efficacy beliefs," Turkish Online J. Educ. Technol., vol. 13, no. 2, pp. 157-167, 2014.

[18] K. Y. Ting and M. S. Chao, "The application of self-regulated strategies to blended learning," English Lang. Teaching, vol. 6, no. 7, pp. 26-32, 2013.

[19] B. R. Quince, "The Effects of Self-Regulated Learning Strategy Instruction and Structured-Diary Use on Students' Self-Regulated Learning Conduct and Academic Success in Online CommunityCollege General Education Courses.," The University of San Fransisco, 2013. 